\title{
Artikel Penelitian \\ Ekstraksi Teh Putih Berbantu Ultrasonik pada Berbagai Amplitudo
}

\section{Extraction of White Tea by Ultrasound Assisted Extraction at Various Amplitude}

Asri Widyasanti $^{1 *}$, Tri Halimah ${ }^{1}$, Dadan Rohdiana ${ }^{2}$

${ }^{1}$ Laboratorium Pascapanen dan Teknologi Proses, Program Studi Teknik Pertanian, Fakultas Teknologi Industri Pertanian, Universitas

Padjadjaran, Jatinangor

${ }^{2}$ Pusat Penelitian Teh dan Kina, Bandung

*Korespondensi dengan penulis (asri.widyasanti@unpad.ac.id)

Artikel ini dikirim pada tanggal 27 Februari 2018 dan dinyatakan diterima tanggal 23 Agustus 2018. Artikel ini juga dipublikasi secara online melalui https://ejournal2.undip.ac.id/index.php/jatp. Hak cipta dilindungi undang-undang. Dilarang diperbanyak untuk tujuan komersial.

Diproduksi oleh Indonesian Food Technologists ${ }^{\circledR}$ (C2018

\section{Abstrak}

Tujuan dari penelitian ini adalah untuk mengetahui pengaruh amplitudo yang berbeda terhadap sifat fisikokimia ekstrak teh putih dengan menggunakan Ultrasound Assisted Extraction (UAE). Ekstraksi dilakukan menggunakan pelarut etanol 96\% serta ukuran bubuk teh putih 18 mesh. Sonikasi digunakan pada amplitudo 25, 50, 75 dan 100\%. Metode yang digunakan adalah percobaan laboratorium dengan analisis deskriptif. Parameter uji yang dilakukan meliputi rendemen total, kadar sisa pelarut, bobot jenis, warna, dan kadar polifenol. Hasil penelitian menunjukkan perbedaan penggunaan amplitudo pada proses ekstraksi mempengaruhi nilai rendemen ekstraksi dan mutu ekstrak dengan penggunaan amplitudo $100 \%$ sebagai perlakuan terbaik dengan nilai rendemen total sebesar $67,35 \%$; nilai bobot jenis filtrat 0,8241; bobot jenis ekstrak sebesar 1,0306; dan kadar polifenol sebesar 0,90 mg asam galat ekivalen/g bobot kering. Hasil menunjukkan nilai yang lebih baik dibandingkan dengan maserasi dengan rendemen ekstraksi hasil maserasi 60,12 \%; nilai bobot jenis filtrat 0,8163; bobot jenis ekstrak sebesar 1,0053; dan kadar polifenol sebesar $0,64 \mathrm{mg}$ asam galat ekivalen/g bobot kering. Karakteristik warna ekstrak etanol teh putih seluruh perlakuan amplitudo dan maserasi menghasilkan kromatisitas warna merah. Kesimpulan dari penelitian ini adalah adanya pengaruh teknik sonikasi pada sifat fisikokimia ekstrak teh putih dan ekstraksi menggunakan amplitudo $100 \%$ menghasilkan nilai rendemen dan kadar polifenol terbaik.

Kata kunci: amplitudo, ekstrak, ekstraksi berbantu ultrasonik, teh putih

\begin{abstract}
The purpose of this study was to determine the effect of different amplitudes on physicochemical properties of white tea extract using Ultrasound Assisted Extraction (UAE). Ethanol was used as solvent and material size was 18 mesh. This research used amplitude: 25, 50, 75, and 100\%. The method used laboratory experiment using descriptive analysis. The parameters were total extraction total yield, residual solvent content, specific gravity, colour, and total polyphenol. The result showed that the amplitude in extraction process influenced the yield and the quality of the extract. As much as $100 \%$ amplitude was the best treatment resulted in total yield of $67.35 \%$; the specific gravity of filtrate was 0.8241; the specific gravity of extract was 1.0306; and the polyphenol content was $0.90 \mathrm{mgGAE}$ $1 \mathrm{~g}$ dryweight. The result of UAE showed a better result than hot maceration with total yield of $60.12 \%$; specific gravity of filtrate was 0.8163; specific gravity of extract was 1.0053; and polyphenol content was $0.64 \mathrm{mgGAE} / \mathrm{g}$ dry weight. Colour characteristics of white tea ethanol extracts from all operating amplitude and hot maceration were resulting in red colour. As conclusion, ultrasound technique provided the physicochemical properties changes of extract and $100 \%$ amplitude was resulting best value of yield and polyphenol content.
\end{abstract}

Keywords: amplitude; extract; ultrasound assisted extraction; white tea

\section{PENDAHULUAN}

Teh dianggap menyehatkan karena mengandung polifenol, vitamin, mineral, alkaloid, asam amino, dan minyak atsiri. Meskipun lebih langka dan mahal daripada teh hijau dan teh hitam, teh putih dikonsumsi karena kemungkinan implikasinya bagi kesehatan. Teh putih dan hijau dianggap sangat bermanfaat karena memiliki jumlah dari epigallocatechin-gallate (EGCG) yang tinggi, sebagai polifenol biologis aktif (Ho, et al., 2009). Produksi tahunan teh putih tergolong relatif kecil, yaitu hanya 2.000 ton atau sekitar $0,1 \%$ dari produksi teh hitam (Ho, et al., 2009). Hal ini dikarenakan produksi teh putih yang hanya dari helaian pucuk daun Camellia sinensis yang sangat muda dan belum mekar yang dipetik dengan penuh kehati-hatian (Balai Penelitian Tanaman Industri dan Penyegar, 2013).

Potensi dari teh putih tidak sejalan dengan tingkat produksinya. Industri hilir banyak memanfaatkan ekstrak polifenol dari ekstrak teh hijau yang kandungan polifenolnya tinggi sebagai bahan baku industri makanan dan minuman, industri farmasi dan kosmetik. Peredaran produk ekstrak polifenol sangat terbatas di Indonesia dan masih diimpor (Hara, 2008). Polifenol (katekin) dapat diekstraksi dari sumber tanaman dan diubah dalam bentuk yang sesuai. Ekstraksi/isolasi katekin menjadi bentuk yang stabil dinilai sulit, mengingat stabilitas oksidatif katekin yang rendah (Gadkari dan Balaraman, 2015). Sistem ekstraksi efisien yang dapat digunakan pada proses ekstraksi produk pangan salah 
satunya adalah ekstraksi yang dibantu dengan menggunakan ultrasonik. Penggunaan ultrasonik pada proses ekstraksi dinilai dapat dilakukan dalam waktu yang singkat dalam hitungan menit dan dengan reproduktivitas tinggi (Chemat, et al., 2011). Ultrasonik merupakan gelombang mekanis, sehingga parameter frekuensi, panjang gelombang, dan amplitudo dapat mempengaruhi proses ekstraksi (Chemat et al., 2016; Bendhico dan Lavilla, 2000). Pada penelitian Horzic, et al. (2012), penggunaan amplitudo pada proses ekstraksi teh kuning dapat ditentukan dengan menggunakan amplitudo sebesar 25, 50, 75, dan $100 \%$. Namun perlu diketahui pula apakah perbedaan amplitudo yang digunakan memberikan pengaruh pada mutu dari ekstrak teh putih. Penelitian ini bertujuan untuk mengamati pengaruh besar amplitudo yang digunakan terhadap mutu ekstrak teh putih yang meliputi rendemen total, kadar sisa pelarut, bobot jenis, warna, dan kadar polifenol.

\section{Materi dan Metode \\ Materi}

Bahan-bahan yang digunakan pada penelitian ini, yaitu peko teh putih yang diperoleh dari Pusat Penelitian Teh dan Kina Gambung-Bandung, pelarut etanol 96\%, asam galat sebagai standar, $\mathrm{Na}_{2} \mathrm{CO}_{3} 7,5 \%$, reagen Folin-Ciocalteau. Peralatan yang digunakan adalah timbangan digital "Boeco", Ultrasonic processor "Qsonica - Q500" (20 kHz, 500W), rotary vacuum evaporator "Heidolph", grinder "Philips", siever 18 mesh, spetrofotometer CM-5, termometer, beaker glass, kertas saring "Whatman No. 42", pipet, serta peralatan lain yang bersifat sebagai alat bantu penelitian.

\section{Metode}

Penelitian ini menggunakan metode eksperimen laboratorium dengan menggunakan analisis deskriptif. Penelitian berlangsung selama Agustus - Oktober 2017. Penelitian meliputi proses persiapan bahan baku dan pembuatan ekstrak teh putih. Analisis mutu ekstrak meliputi rendemen total, kadar sisa pelarut, bobot jenis, warna, dan kadar polifenol.

\section{Persiapan Bahan Baku}

Peko teh putih kering, dilakukan pengecilan ukuran terlebih dahulu dengan menggunakan grinder yang kemudian diayak dengan menggunakan ayakan tyler. Ukuran bubuk teh yang digunakan yaitu berukuran 18 mesh.

\section{Pembuatan Ekstrak Teh Putih}

Ekstrak teh putih dibuat dengan mencampurkan bubuk teh putih (2 gram) dengan pelarut etanol 96\% (200 $\mathrm{ml}$ ) yang ditempatkan pada gelas piala $250 \mathrm{ml}$. Sampel diekstrak selama 30 menit menggunakan probe dengan frekuensi $20 \mathrm{kHz}$ yang terhubung dengan transduser sehingga diperoleh intensitas yang tinggi. Ujung probe terbuat dari titanium berdiameter 1,2 cm dan dicelupkan ke dalam sampel sehingga sampel teriradiasi dengan gelombang ultrasonik langsung dari ujung probe. Amplitudo yang digunakan pada ekstraksi diatur pada
$25,50,75$, dan $100 \%$, sebagaimana prosedur Horzic et al., (2012). Setiap perlakuan dilakukan sebanyak 3 kali. Setelah dilakukan sonikasi pada sampel, filtrat dan ampas teh putih dipisahkan dengan menggunakan kertas saring Whatman No. 42, kemudian pelarut diuapkan dengan menggunakan rotary evaporator vacuum pada suhu $40^{\circ} \mathrm{C}$ sehingga terbentuk ekstrak kental teh putih.

\section{Perhitungan Rendemen Total Ekstraksi}

Rendemen total merupakan perbandingan massa ekstrak teh putih yang dihasilkan dengan massa bahan baku (teh putih) yang diekstraksi (Widyasanti et al., 2016). Perhitungan rendemen total menggunakan persamaan berikut:

$$
\text { Rendemen total }=\frac{\mathrm{Me}-(\mathrm{Me} \times \mathrm{ksp})}{\mathrm{Ma}} \times 100 \%
$$

Keterangan:

$\mathrm{Me}=$ Massa ekstrak teh putih $(\mathrm{g}), \mathrm{Ma}=$ Massa awal bubuk teh putih (g), $\mathrm{ksp}=$ kadar sisa pelarut

\section{Perhitungan Kadar Sisa Pelarut}

Kadar sisa pelarut (KSP) ditentukan dengan menggambarkan sisa pelarut dalam ekstrak yang dihitung berdasarkan berat pelarut yang diuapkan selama 1 jam pada suhu $50^{\circ} \mathrm{C}$ dari setiap satuan berat bahan yang diuapkan menggunakan rotary evaporator vacuum (Guenther, 1987). Perhitungan kadar sisa pelarut menggunakan persamaan berikut :

$$
\mathrm{KSP}=\frac{\mathrm{b}-\mathrm{c}}{b-a} \times 100 \%
$$

Keterangan :

$\mathrm{a}=$ massa labu evaporator kosong $(\mathrm{g}), \mathrm{b}=$ massa awal labu + ekstrak teh putih (g), c = massa labu + ekstrak setelah dilakukan evaporasi (g)

\section{Perhitungan Bobot Jenis}

Pengukuran bobot jenis ekstrak teh putih didasarkan pada SNI (2006), yaitu perbandingan massa ekstrak teh putih dengan massa air (akuades) pada volume dan suhu yang sama.

Bobot jenis $=\frac{m_{2}-m}{m_{1}-m}$

\section{Keterangan :}

$\mathrm{m}=$ Bobot piknometer kosong $(\mathrm{g}), \mathrm{m}_{1}=$ Bobot piknometer + aquades (g), $\mathrm{m}_{2}=$ Bobot piknometer + ekstrak $(\mathrm{g})$

\section{Perhitungan Warna}

Penentuan warna ekstrak teh putih dilakukan dengan pengolahan citra dengan menggunakan alat analisa warna spektrofotometer CM-5 dalam memperoleh nilai $L^{*}, a^{*}, b^{*}$, chroma, dan Hue (Widyasanti et al., 2016).

\section{Perhitungan Kadar Polifenol}

Kandungan polifenol (KP) dalam ekstrak teh ditentukan secara spektrofotometri dengan pereaksi Folin-Ciocalteu. Secara singkat, 0,05 gram sampel diencerkan dengan metanol hingga $2 \mathrm{ml}$. Dari pengenceran tersebut, sebanyak $0,5 \mathrm{ml}$ sampel yang 
sudah diencerkan dimasukan ke dalam tabung reaksi, kemudian ditambahkan 2,5 ml reagen Folin-Ciocalteau dan $2 \mathrm{ml} \mathrm{Na} \mathrm{CO}_{3} 7,5 \%$. Campuran diinkubasi selama 15 menit pada suhu $45^{\circ} \mathrm{C}$. Absorbansi sampel diukur pada panjang gelombang $765 \mathrm{~nm}$ dengan menggunakan blanko dimana pada campurannya sampel diganti dengan metanol. Sebagai standar, digunakan asam galat. Berdasarkan persamaan linier dari kurva asam galat $(y=a x+b)$ maka dicari nilai kandungan total polifenol (x) dengan y adalah absorbansi sampel ekstrak teh putih dalam satuan $\mathrm{mg}$ asam galat ekivalen/g bobot kering (Shahidi dan Nazck, 2004). Persamaan yang telah dihasilkan untuk menghitung kadar polifenol pada penelitian ini adalah $\mathrm{y}=1,0059 x-0,0013$.

\section{Hasil dan Pembahasan}

Rendemen Total

Rendemen total merupakan perbandingan massa ekstrak teh putih yang dihasilkan dengan massa bahan baku (teh putih) yang digunakan. Rendemen total merupakan parameter terpenting yang diamati dan dianalisis dalam penelitian ini. Nilai rendemen total menentukan amplitudo yang optimal untuk digunakan dalam ekstraksi teh putih dengan menggunakan metode ultrasound assisted extraction.

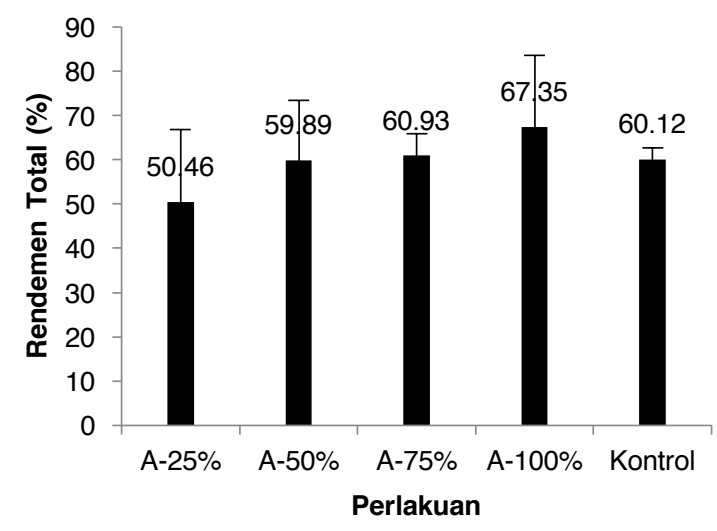

Figur 1. Rendemen Total Ekstraksi Teh Putih

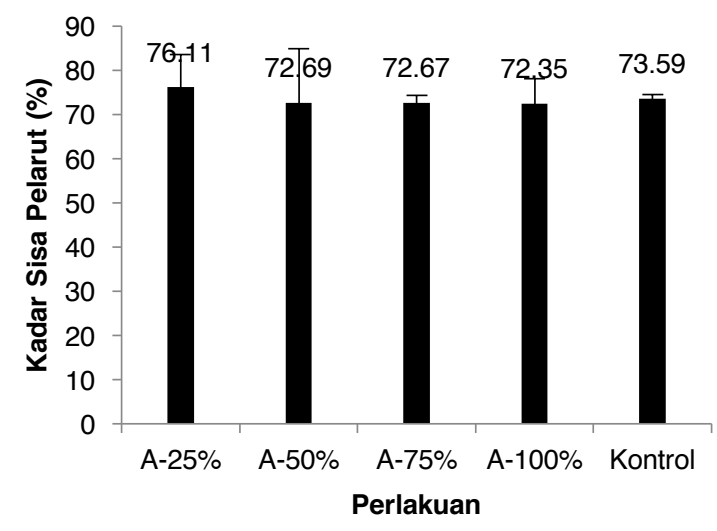

Figur 2. Kadar Sisa Pelarut Ekstrak Teh Putih

Berdasarkan rendemen total ekstraksi teh putih (Figur 1), rendemen total yang dihasilkan semakin meningkat dan berbanding lurus dengan amplitudo yang digunakan. Dibandingkan dengan perlakuan kontrol yang memiliki nilai rendemen total sebesar $60,12 \%$, maka penggunaan amplitudo 75 dan $100 \%$ menghasilkan nilai yang lebih tinggi yaitu masing-masing sebesar 60,93 dan 67,35\%. Amplitudo pada proses ekstraksi terkait dengan intensitas sonikasi (Wardiyati, 2004). Menurut Asbahani et al., (2015) penggunaan ekstrasi ultrasonik memberikan keuntungan intensifikasi transfer massa, perusakan sel, dan peningkatan penetrasi pelarut dan efek kapiler, sehingga senyawasenyawa pada teh putih lebih banyak terekstrak.

Penggunaan pelarut etanol $96 \%$ yang bersifat polar juga mempengaruhi rendemen total. Menurut Shahidi dan Nazck (2004), kandungan utama polifenol teh adalah flavanol (katekin, galokatekin, epikatekin, epikatekin galat, epigalokatekin, epigalokatekin galat), flavonol, flavone (vixetin dan iso vixetin), asam fenolik (asam galat dan asam klorogenat) dapat terlarut dengan baik pada pelarut polar. Sebanyak $35 \%$ dari berat kering teh merupakan senyawa golongan polifenol yang sebagian bersifat polar (Shahidi dan Nazck, 2004). Pelarut yang bersifat polar juga mampu mengekstrak senyawa alkaloid kuartener, komponen fenolik, karotenoid, tannin, gula, asam amino, dan glikosida (Harbone, 1987).

\section{Kadar Sisa Pelarut}

Kadar sisa pelarut menyatakan banyaknya pelarut yang masih tersisa pada ekstrak teh putih. Nilai ini diperoleh dari persentase berat pelarut yang diuapkan dari satuan berat bahan yang diuji. Parameter ini merupakan parameter yang penting, karena jumlah pelarut yang masih terkandung pada ekstrak dapat mengganggu kesehatan jika dikonsumsi. Kadar sisa pelarut ekstrak teh putih pada setiap perlakuan tersaji pada Figur 2.

Berdasarkan peraturan Badan Pengawasan Obat dan Makanan (BPOM, 2005) tentang kriteria dan tata laksana pendaftaran obat tradisional, obat harbal terstandar, dan fitofarmaka, kandungan etil alkohol pada obat dalam bentuk sediaan cairan tidak boleh melebihi $1 \%$. Berdasarkan nilai kadar sisa pelarut diantara seluruh perlakuan, baik yang menggunakan ekstraksi ultrasonik maupun kontrol (maserasi), memiliki nilai yang sangat tinggi, sehingga ekstrak teh putih yang dihasilkan masih belum memenuhi standar sebagai bahan pangan maupun farmasi. Hal ini diduga terjadi karena penggunaan perbandingan bahan dan pelarut yang digunakan yaitu sebesar 1:100.

\section{Analisis Warna}

Warna merupakan parameter yang berpengaruh langsung terhadap sensori manusia. Pengujian warna menggunakan alat khusus agar nilai yang dihasilkan dapat bersifat objektif dan kuantitatif. Alat yang digunakan pada penelitian ini yaitu, Chroma Minoltaspektrofotometer CM 5. Pada alat ini, dihubungkan dengan perangkat lunak sehingga data yang dihasilkan dapat disimpan. Hasil uji dengan menggunakan alat ini menghasilkan nilai $L^{*}, a^{*}, b^{*}, C$, dan Hue secara langsung. Pada penelitian ini dilakukan pengujian warna 
masing-masing sampel ekstrak teh putih termasuk perlakuan kontrol. Hasil pengujian warna $\left(L^{*}, a^{*}, b^{\star}\right)$, nilai kroma dan Hue terdapat pada Tabel 1.

Notasi $L^{*}$ menyatakan kecerahan pada ekstrak teh putih. Nilai $L^{*}$ berkisar antara 0 (hitam) hingga 100 (putih) (Suyatma, 2009). Berdasarkan hasil pengujian warna, nilai $L^{*}$ dari ekstrak teh putih menunjukkan nilai yang semakin kecil pada penggunaan amplitudo yang semakin besar. Nilai $L^{*}$ dari ekstrak teh putih dengan menggunakan ketiga pelarut tersebut kurang dari 30, sehingga ekstrak tersebut digolongkan agak gelap.

Notasi $a^{*}$ menyatakan warna campuran merah dan hijau. Nilai $a^{\star}$ dari 0 sampai 80 maka menyatakan warna merah dan nilai $a^{*}$ dari -80 sampai 0 menyatakan warna hijau (Suyatma, 2009). Pada ekstrak teh putih setiap perlakuan menghasilkan $a^{*}$ bernilai positif yaitu berkisar antara 2,02 sampai 15,50 dan dapat dikatakan ekstrak berwarna merah. Ekstrak teh putih dengan perlakuan amplitudo $25 \%$ memiliki nilai a* tertinggi.

Notasi $b^{*}$ menyatakan warna campuran biru dan kuning. Nilai $b^{\star}$ dari 0 sampai 70 maka menyatakan warna kuning dan nilai $b^{\star}$ dari -70 sampai 0 menyatakan warna biru (Suyatma, 2009). Pada ekstrak teh putih setiap perlakuan menghasilkan $b^{*}$ bernilai positif yaitu berkisar antara 2,63 sampai 19,98 dan dapat dikatakan ekstrak berwarna kuning. Ekstrak teh putih dengan perlakuan amplitudo $25 \%$ memiliki nilai $b^{*}$ tertinggi.
Chroma/Saturation adalah derajat intensitas suatu warna untuk mendefinisikan kemurnian suatu warna, baik cenderung kotor (grayish) maupun cenderung dominan (murni). Semakin tinggi nilai chroma (C), intensitas warnanya semakin rendah. Berdasarkan hasil penelitian didapatkan nilai chorma 3,32 sampai 25,30 , dengan nilai $\mathrm{C}$ tertinggi terdapat pada ekstrak teh putih perlakuan amplitudo $25 \%$. Nilai Hue mewakili panjang gelombang dari warna yang dominan. Nilai Hue didapatkan dari $a^{*}$ dan $b^{*}$. Nilai Hue ini akan disesuaikan dengan daerah kisaran warna kromatisitas (skala Hutching) dan dapat dihasilkan jenis warna ekstrak. Pada penelitian ini nilai Hue rata-rata berkisar antara 93,63 sampai 96,19 sehingga seluruh masuk dalam daerah kisaran warna kromatisitas Red atau Merah. Warna yang ada pada ekstrak diduga berasal dari flavonoid, tannin, betalain, kuinon dan xanton.

\section{Analisis Bobot Jenis}

Bobot jenis ekstrak dihitung berdasarkan perbandingan bobot dari suatu volume sampel dengan massa air pada suhu dan volume yang sama. Bobot jenis menjelaskan banyaknya komponen yang terkandung dalam zat tersebut serta menunjukkan fraksi berat komponennya. Semakin besar nilai bobot jenis maka komponen yang terkandung di dalam zat tersebut semakin banyak dengan berat molekul yang tinggi. Nilai

Tabel 1. Data Hasil Pengujian Warna

\begin{tabular}{ccccccc}
\hline \multirow{2}{*}{ Perlakuan } & \multicolumn{5}{c}{ Parameter Warna } & Warna \\
\cline { 2 - 6 } & $\mathrm{L}^{*}$ & $\mathrm{a}^{*}$ & $\mathrm{~b}^{*}$ & $\mathrm{C}$ & $\mathrm{h}$ & \\
\hline $\mathrm{A}-25 \%$ & $22,85 \pm 2,81$ & $15,50 \pm 1,23$ & $19,98 \pm 3,44$ & $25,30 \pm 3,48$ & $51,97 \pm 2,45$ & Merah \\
$\mathrm{A}-50 \%$ & $15,74 \pm 1,54$ & $17,48 \pm 3,15$ & $12,08 \pm 2,98$ & $21,25 \pm 4,26$ & $34,43 \pm 2,13$ & Merah \\
$\mathrm{A}-75 \%$ & $13,77 \pm 1,48$ & $11,09 \pm 7,74$ & $7,71 \pm 6,46$ & $13,53 \pm 10,03$ & $33,19 \pm 4,94$ & Merah \\
A-100\% & $7,33 \pm 1,75$ & $5,30 \pm 1,44$ & $2,71 \pm 0,57$ & $5,96 \pm 1,54$ & $27,42 \pm 1,92$ & Merah \\
Kontrol & $11,85 \pm 6,62$ & $2,02 \pm 0,66$ & $2,63 \pm$ & $3,32 \pm 1,22$ & $51,66 \pm 4,03$ & Merah \\
\hline
\end{tabular}

Tabel 2. Bobot Jenis Filtrat dan Ekstrak Teh Putih

\begin{tabular}{ccc}
\hline Perlakuan & Bobot Jenis Filtrat & Bobot Jenis Eksrak \\
\hline A-25\% & $0,8115 \pm 0,003$ & $1,0104 \pm 0,008$ \\
A-50\% & $0,8168 \pm 0,001$ & $1,0197 \pm 0,003$ \\
A-75\% & $0,8171 \pm 0,001$ & $1,0222 \pm 0,009$ \\
A-100\% & $0,8241 \pm 0,001$ & $1,0306 \pm 0,004$ \\
Kontrol & $0,8163 \pm 0,002$ & $1,0053 \pm 0,001$ \\
\hline
\end{tabular}

Tabel 3. Rekapitulasi Nilai Rendemen dan Mutu Ekstrak Teh Putih Terbaik

\begin{tabular}{|c|c|c|c|c|c|c|c|c|}
\hline \multirow{2}{*}{\multicolumn{2}{|c|}{ Parameter }} & \multicolumn{4}{|c|}{ Perlakuan } & \multirow{3}{*}{$\begin{array}{l}\text { Kontrol } \\
60,12\end{array}$} & \multirow{2}{*}{\multicolumn{2}{|c|}{ Referensi }} \\
\hline & & \multirow{2}{*}{$\begin{array}{c}\text { A- } \\
25 \% \\
50,46\end{array}$} & \multirow{2}{*}{$\begin{array}{c}\text { A- } \\
50 \% \\
59,46\end{array}$} & \multirow{2}{*}{$\begin{array}{c}\text { A- } \\
75 \% \\
60,93\end{array}$} & \multirow{2}{*}{$\begin{array}{c}A-100 \% \\
67,35\end{array}$} & & & \\
\hline Rendem & Total (\%) & & & & & & $\begin{array}{l}\text { Rendemen } \\
\text { Terbesar }\end{array}$ & $\begin{array}{l}\text { Chemat } \\
\text { (2011) }\end{array}$ \\
\hline \multirow{4}{*}{ Warna } & $L^{*}$ & 22,85 & 15,74 & 13,77 & 7,33 & 11,85 & $L$ terbesar & \multirow{4}{*}{$\begin{array}{c}\text { Najib, } \\
\text { et al. (2017) }\end{array}$} \\
\hline & $a^{*}$ & 15,50 & 17,48 & 11,09 & 5,30 & 2,02 & $\mathrm{a}^{*}$ terkecil & \\
\hline & C & 25,30 & 21,25 & 13,53 & 5,96 & 3,32 & C terbesar & \\
\hline & $\mathrm{H}$ & 51,97 & 34,43 & 33,19 & 27,42 & 51,66 & $\mathrm{H}$ terbesar & \\
\hline \multirow{2}{*}{$\begin{array}{l}\text { Bobot } \\
\text { Jenis }\end{array}$} & Filtrat & 0,8115 & 0,8168 & 0,8171 & 0,8241 & 0,8163 & \multirow{2}{*}{$\begin{array}{c}\text { Bobot jenis } \\
\text { terbesar }\end{array}$} & \multirow{2}{*}{$\begin{array}{c}\text { Sofyana, et } \\
\text { al. (2013) }\end{array}$} \\
\hline & Ekstrak & 1,0104 & 1,0197 & 1,0222 & 1,0306 & 1,0053 & & \\
\hline \multicolumn{2}{|c|}{ Kadar Sisa Pelarut (\%) } & 76,11 & 72,69 & 72,67 & 72,35 & 73,59 & $\mathrm{KSP}<1 \%$ & $\begin{array}{l}\text { BPOM } \\
(2005)\end{array}$ \\
\hline \multicolumn{2}{|c|}{ Kadar Polifenol (mg/g) } & 0,549 & 0,676 & 0,753 & 0,897 & 0,640 & $\begin{array}{c}\text { Kadar Polifenol } \\
\text { terbesar }\end{array}$ & $\begin{array}{c}\text { Shahidi dan } \\
\text { Nazck (2004) }\end{array}$ \\
\hline
\end{tabular}

Keterangan : Bagian yang diblok merupakan perlakuan terbaik 
bobot jenis filtrat dan ekstrak dari setiap perlakuan tersaji pada Tabel 2.

Berdasarkan data bobot jenis filtrat dan ekstrak teh putih, bobot jenis filtrat memiliki nilai lebih besar dari massa jenis pelarut yaitu $0,798 \mathrm{~g} / \mathrm{ml}$. Hal ini diduga disebabkan karena pelarut etanol mengikat senyawa yang ada pada teh putih. Nilai bobot jenis filtrat dan ekstrak menunjukkan nilai yang semakin meningkat karena diduga adanya perlakuan amplitudo berpengaruh terhadap nilai bobot jenis. Semakin besar amplitudo, maka semakin tinggi pula nilai bobot jenis ekstrak teh putih yang dihasilkan. Hal ini dimungkinkan karena semakin besar amplitudo maka semakin banyak komponen yang terekstraksi dari dalam teh putih. Dari hasil yang diperoleh, bobot jenis ekstrak teh putih adalah $>1$ dan lebih berat daripada air. Maka dapat dikatakan bahwa bentuk fisik ekstrak teh putih berbentuk kental dan tenggelam di dalam air.

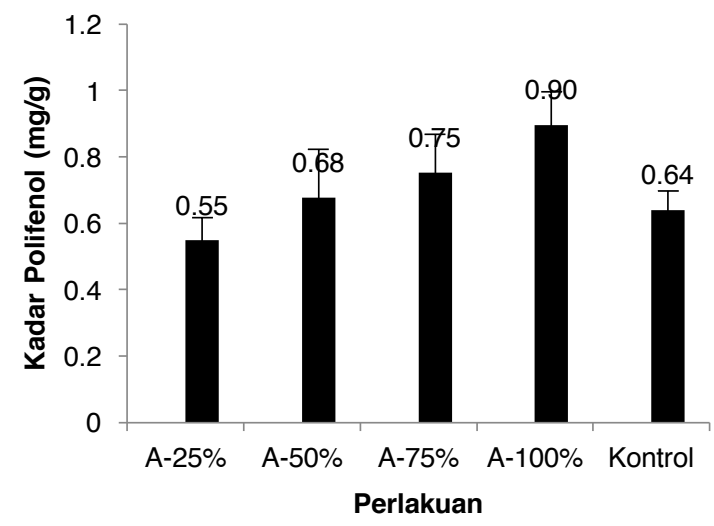

Figur 3. Kadar Polifenol Ekstrak Teh Putih dan Bubuk Teh Putih

\section{Analisis Kadar Polifenol}

Parameter kadar polifenol merupakan salah satu parameter yang penting dalam mutu teh. Senyawa polifenol ini dapat dimanfaatkan pada industri pangan (makanan atau minuman) dan non-pangan (farmasi atau kosmetik), sebagai bahan yang memberikan keuntungan terkait kesehatan tubuh manusia (Gadkari dan Balaraman, 2015). Penetapan kadar polifenol dilakukan dengan menggunakan reagen Folin-Ciocalteu (FC). Reagen ini mengandung fosfomolibdat-fosfotungstat yang akan mengoksidasi gugus hidroksil $(-\mathrm{OH})$ dari senyawa fenol menghasilkan senyawa komplek berwarna biru. Reaksi ini berjalan lambat pada suasana asam sehingga pada saat reaksi ditambahkan $\mathrm{Na}_{2} \mathrm{CO}_{3}$ untuk membentuk suasana basa sehingga reaksi dapat berjalan lebih cepat (Agustiningsih, 2010). Pada penelitian ini digunakan asam galat sebagai senyawa fenol pembanding. Asam galat merupakan golongan asam fenolik atau hidroksibenzoat yang mudah diperoleh dalam kondisi stabil dan murni, serta lebih murah dibandingkan dengan senyawa standar lainnya (Lestari, et al., 2015).

Berdasarkan kadar polifenol dari ekstrak dan bubuk teh (Figur 3.) menunjukkan bahwa pada perlakuan amplitudo $100 \%$ dihasilkan jumlah polifenol yang lebih besar dibandingkan dengan kadar polifenol dari perlakuan yang lain. Semakin besar amplitudo yang digunakan maka nilai kadar polifenol yang terekstrak semakin banyak. Hal ini diduga disebabkan semakin besar amplitudo, maka pembentukan reaksi kavitasi semakin besar sehingga pelepasan senyawa yang terkstrak atau transportasi massa semakin meningkat. Dibandingkan dengan kontrol, nilai kadar polifenol pada perlakuan amplitudo 50\%, 75\%, 100\% memiliki nilai yang lebih besar. Hal ini menunjukkan bahwa penggunaan ekstraksi berbantu ultrasonik memberikan hasil yang lebih baik dibandingkan dengan ekstraksi konvensional pada lama ekstraksi yang sama. Kadar polifenol pada bubuk teh memiliki nilai yang paling kecil, hal ini menunjukkan bahwa dengan adanya proses ekstraksi, maka senyawa-senyawa yang terdapat pada teh dapat di ambil dari jaringan yang mengikat karena adanya transportasi massa dari bahan ke pelarut sehingga hasil dari proses ekstraksi dapat dimanfaatkan dalam industri farmasi atau kosmetik.

\section{Rekapitulasi Hasil Terbaik}

Terdapat empat perlakuan yang berbeda pada penelitian ini yaitu perlakuan perbedaan amplitudo yang digunakan yaitu 25\%, 50\%, 75\%, 100\%. Perbedaan perlakuan ini dilakukan untuk mengetahui amplitudo yang optimal untuk mengekstraksi teh putih dengan metode ultrasound assisted extraction. Perlakuan yang optimal ini dapat diketahui berdasarkan analisis rendemen dan mutu ekstrak teh putih yang dihasilkan. Rendemen yang digunakan untuk menentukan hasil ekstrak teh putih terbaik adalah rendemen total. Sedangkan parameter mutu yang digunakan untuk menentukan ekstrak teh putih terbaik terdiri dari warna, bobot jenis, kadar sisa pelarut, dan kadar polifenol.

Berdasarkan rekapitulasi hasil terbaik ekstrak teh putih (Tabel 3), dapat dilihat bahwa rendemen tertinggi dari keempat perlakuan adalah penggunaan amplitudo $100 \%$ yaitu sebesar $67,35 \%$, kemudian rendemen tertinggi kedua setelah perlakuan amplitudo 100\% adalah rendemen perlakuan amplitudo $75 \%$ yaitu sebesar $60,93 \%$ dan rendemen terendah adalah rendemen dengan amplitudo 25\%. Sedangkan dilihat berdasarkan mutu, dari keempat parameter yang dianalisis, salah satu parameter, yaitu warna menyatakan bahwa perlakuan amplitudo 25\% yang paling baik. Namun pada parameter warna, nilai $a^{*}$ terbaik dinyatakan pada perlakuan kontrol, karena ekstrak teh yang diharapkan memiliki nilai $a^{*}$ terkecil yang menyatakan warna ekstrak cenderung berwarna hijau. Adapun dua parameter lain yaitu parameter bobot jenis dan kadar polifenol menunjukkan bahwa perlakuan terbaik adalah perlakuan amplitudo $100 \%$. Sedangkan, parameter kadar sisa pelarut disimpulkan tidak ada perlakuan yang menyatakan hasil terbaik. Hal ini karena pada referensi dinyatakan bahwa kadar sisa pelarut harus bernilai kurang dari 1\%, sedangkan nilai kadar sisa pelarut seluruh perlakuan, memiliki nilai yang sangat tinggi. Berdasarkan hasil rekapitulasi tersebut dapat diambil kesimpulan bahwa perlakuan terbaik pada penelitian ini adalah perlakuan amplitudo 100\%. 


\section{Kesimpulan}

Perbedaan penggunaan amplitudo pada proses ekstraksi dapat mempengaruhi nilai rendemen ekstraksi dengan nilai rendemen total sebesar 67,35\% pada penggunaan amplitudo $100 \%$. Perbedaan penggunaan amplitudo pada proses ekstraksi juga mempengaruhi mutu ekstrak dengan perlakuan amplitudo $100 \%$ memberikan hasil terbaik yaitu nilai bobot jenis filtrat 0,8241 ; bobot jenis ekstrak sebesar 1,0306; dan kadar polifenol sebesar $0,90 \mathrm{mg}$ asam galat ekivalen/g bobot kering.

\section{Daftar Pustaka}

Agustiningsih, Wildan, A., Mindaningsih. 2010. Optimasi cairan penyari pada pembuatan ekstrak daun pandan wangi (Pandanus amaryllifous Roxb) secara maserasi terhadap kadar fenolik dan flavonoid total. Jurnal Momentum 6 (2): 36-41.

Asbahani, A.El., Miladi, K., Badri, W., Sala, M., Ait Addi, E.H., Casabianca, H., Mousadik, A.El., Hartmann, D., Jilale, A., Renaud, F.N.R., Elaissari, A. 2015. Essential oils: from extraction to encapsulation. International Journal of Pharmaceutics 483: 220243. DOI:10.1016/j.ijpharm.2014.12.069.

Balai Penelitian Tanaman Industri dan Penyegar. 2013. Teh putih yang langka dan mahal. Terdapat pada http://balittri.litbang.pertanian.go.id/index.php/beri ta/info-teknologi/177-teh-putih-yang-langka-danmahal (Diakses pada tanggal 27 Maret 2017 pukul 16.03)

Bendicho, C., Lavilla, I. 2000. Ultrasound extractions. Spain: Academic Press.

BPOM RI. 2005. Peraturan kepala badan pengawasan obat dan makanan republik indonesia nomor HK 00.05.41.1384 tentang kriteria dan tata laksana pendaftaran obat tradisional, obat herbal terstandar dan fitofarmaka. Jakarta.

Chemat, F., Zill-e-Huma, Muhammed, K. 2011. Applications of ultrasound in food technology: processing, preservation dan extraction. Journal Ultrasonic Sonochemistry 18: 813-835. DOI:10.1016/j.ultsonch.2010.11.023.

Chemat, F., Rombaut, N., Sicaire, A.G., Meullemiestre, A., Fabiano-Tixier, A., Abert-Vian, M. 2016. Ultrasound assisted extraction of food and natural products: mechanism, techniques, combinations, protocols and application. Journal Ultrasonics Sonochemistry 34: 310-316. DOI: 10.1016/ j.ultsonch.2016.06.035

Lestari, T. Agnis, N., Mira, N. 2015. Penetapan kadar polifenol dan aktivitas antibakteri ekstrak etanol daun sintrong (Crassocephalum crepidiodes (Benth.) S. moore). Jurnal Kesehatan Bakti Tunas Husada 13 (1): 107-112.
Gadkari, P.V., Balaraman, M. 2015. Catechins: Sources, Extraction and Encapsulation: A Riview. Food and Bioproducts Processing 93: 122-138.DOI: http://dx.doi.org/10.1007/s13197-013-1085-9.

Guenther, E. 1987. Minyak Atsiri Jilid I (Penerjemah S. Ketaren). Universitas Indonesia, Jakarta.

Hara, Y. 2008. Development of tea catechin into pharmaceuticals. Proceeding of the 3rd International conference on OCHA (Tea) Culture and Science, Japan: Shizuoka.

Harborne, J. B. 1987. Metode Fitokimia. Bandung: Institut Teknologi Bandung.

Ho, Chi-Tang, Lin, Jen-Kun, Shahidi, Fereidoon. 2009. Nutraceutical science and technology. CRC Press. New York.

Horzic, D., Jambrak, A.R., Belscak-Cvitanovic, A., Komes, D., Lelas, V. 2012. Comparison of conventional and ultrasound assisted extraction techniques of yellow tea and bioactive composition of obtained extracts. Food Bioprocess Technol. Original Paper. DOI 10.1007/s11947-012-0791-z.

Najib, A., Abdul, M., Aktsar, R.A., Virsa, H., Rezki, A.S., Risda, W. 2017. Standarisasi ekstrak air daun jati belanda dan teh hijau. Jurnal Fitofarmaka Indonesia 4 (2): 241-245.

Shahidi, F., Naczk, M. 2004. Phenolics in Food and Nutraceuticals. CRC Press. Boca Raton

SNI (Standar Nasional Indonesia) 06-2387-2006. 2006. Minyak Daun Cengkih. Badan Standarisasi Nasional. Jakarta.

Suyatma. 2009. Diagram warna hunter (kajian pustaka). Jurnal Penelitian Ilmiah Teknologi Pertanian. Bogor: Institut Pertanian Bogor.

Sofyana, M., Dani, S., Zuhra, Cut, A.M., Ulfa, H. 2013. Ultrasound assisted extraction of oleoresin from nutmeg (Myristia fragrans Houtt). International Journal on Advanced Science Engineering Information Technology 3 (4) : 18-21. DOI:http:// dx.doi.org/10.18517/ijaseit.3.4.298.

Wardiyati S. 2004. Pemanfaatan ultrasonik dalam bidang Kimia. Prosiding Pertemuan Imiah IImu Pengetahuan dan Teknologi Bahan, Puslitbang Iptek Bahan (P3IB)-BATAN: 419-424. Terdapat pada http://digilib.batan.go.id/ppin/katalog/file/ 1411-2213-2004-1-419.pdf (Diakses pada 26 Maret 2017 pukul 17.30).

Widyasanti, A., Priantiwi, A.M., Rohdiana, D. 2016. Aktivitas antibakteri Bacillus cereus dan Shigella dysenteriae ekstrak teh putih dalam variasi jenis pelarut. Jurnal Penelitian Teh dan Kina 19 (1) : 4156. DOI: 10.22302/pptk.jur.jptk.v19i1.81 